Ilmu Ilmu Agribisnis: Journal of Agribusiness Science, 9(3), Agustus 2021

\title{
ANALISIS MANFAAT EKONOMI DAN FAKTOR-FAKTOR YANG MEMPENGARUHI KELANCARAN PENGEMBALIAN KREDIT (STUDI KASUS PADA KOPERASI PERTANIAN SEANDANAN KABUPATEN PESAWARAN)
}

\author{
(Analysis of Economic Benefits and Factors Affecting the Smoothness Rate of the Credit Return of \\ Seandanan Agricultural Cooperatives in Pesawaran District)
}

\author{
Roni Mustofa, Dyah Aring Hepiana Lestari, dan Muhammad Irfan Affandi \\ Jurusan Agribisnis, Fakultas Pertanian, Universitas Lampung, Jl. Prof. Dr. Soemantri Brojonegoro No.1 \\ Bandar Lampung 35145,e-mail: dyah.aring@fp.unila.ac.id
}

\begin{abstract}
This study aims to analyze the economic benefits, income of rice farming, allocation of credit usage and analyze the factors affecting the chances of the smoothness rate of return at Seandanan Agricultural Cooperatives. The research is conducted at Seandanan Agricultural Cooperative in Pesawaran Regency, Lampung Province, which is determined intentionally. The research data were taken in July 2019. This study uses a case study method. Respondents in this study are 70 rice farmers member of Seandanan Agricultural Cooperative. The data analysis method use descriptive qualitative and quantitative analyses. The results showed that the economic benefits received by members of cooperative in one year is IDR1,711,312.47 and in high category. The average income of rice farming received by members of the Seandanan Agricultural Cooperative in one year has been classified as high, in the amount over cash costs and over total costs, respectively, of IDR17,308,552.78 and IDR16,416,268.56. Allocation of credit of cooperative membersconsistd of $58.85 \%$ for productive activities and the rest, $41.15 \%$ for consumptive activities. Factors that affect the chances of the smoothness rate of credit return by rice farmers members of Seandanan Agricultural Cooperative are the education level of farmers and the allocation of productive credit usage.
\end{abstract}

Key words: agricultural cooperatives, consumptive, credit, and productive

\section{PENDAHULUAN}

Salah satu pilar pembangunan ekonomi Indonesia yang berperan dalam pengembangan sektor pertanian adalah koperasi. Koperasi sebagai sokoguru perekonomian nasional mempunyai kedudukan dan peran yang sangat strategis dalam menumbuhkan dan mengembangkan potensi ekonomi rakyat. Hal ini, dapat dilihat dari fungsi koperasi, yaitu sebagai pendorong perekonomian masyarakat dan berdampak pada kesejahteraan yang merata. Pengembangan koperasi dapat dijadikan sebagai sebuah wahana yang efektif bagi anggota untuk saling bekerjasama, membuka akses pasar, modal, informasi, teknologi dengan mengoptimalkan potensi, dan memanfaatkan peluang usaha yang terbuka (Roepke 2003).

Salah satu kabupaten di Provinsi Lampung yang memiliki jumlah koperasi tidak aktif lebih banyak dibandingkan dengan koperasi aktif adalah Kabupaten Pesawaran. Jumlah koperasi tidak aktif adalah 109 unit atau 51,66 persen dari jumlah keseluruhan koperasi yang ada di Kabupaten
Pesawaran. Beberapa faktor yang mempengaruhi koperasi menjadi tidak aktif, antara lain kurangnya modal, sumberdaya manusia kurang terampil, dan sumber informasi terbatas (Febrianka 2016).

Menurut Batubara (2012), koperasi pertanian adalah koperasi yang menjalankan usaha pemenuhan kebutuhan usahatani antara lain mengusahakan pembelian sarana produksi pertanian, mengolah hasil pertanian, menyediakan kredit bagi petani, dan mengusahakan pasar penjualan hasil-hasil pertanian. Salah satu koperasi pertanian yang memiliki peran penting dalam menunjang sektor pertanian di Kabupaten Pesawaran yaitu Koperasi Pertanian Seandanan yang lokasinya berada di Jalan Raya Kedondong, Desa Tanjung Agung, Kecamatan Way Lima.

Koperasi Pertanian Seandanan adalah koperasi yang memiliki unit usaha tunggal yaitu unit usaha simpan pinjam yang memiliki suku bunga lebih rendah dibandingkan suku bunga lembaga peminjaman di luar koperasi. Hal ini sangat membantu petani yang menjadi anggota koperasi 


\section{Ilmu Ilmu Agribisnis: Journal of Agribusiness Science, 9(3), Agustus 2021}

dalam mendapatkan modal untuk menjalankan usahatani. Selain itu petani anggota koperasi juga memperoleh manfaat ekonomi berupa SHU yang dapat berkontribusi terhadap pendapatan rumah tangga petani. Berdasarkan buku RAT tahun 2017 anggota Koperasi Pertanian Seandanan adalah petani kakao dan padi dengan jumlah 87 orang, dengan rincian 70 orang petani padi, 9 orang petani kakao dan 8 orang petani padi dan kakao.

Permasalahan yang dihadapi koperasi adalah tidak lancarnya anggota dalam membayar kredit yang diduga disebabkan oleh rendahnya pedapatan rumah tangga dan kelalaian anggota dalam menggunakan kredit. Rendahnya pendapatan rumah tangga disebabkan oleh serangan hama dan penyakit terhadap tanaman petani yang mengakibatkan penurunan produksi sehingga berdampak pada pendapatan rumah tangga petani, sedangkan tidak lancarnya anggota membayar kredit karena kelalaian anggota dalam mengalokasikan kredit yang sebagian besar banyak digunakan untuk kegiatan konsumtif. Hal ini dapat mengganggu jalannya usaha simpan pinjam koperasi karena modal tertahan pada anggota yang tidak membayar kredit dimana sebagian besar modal koperasi berasal dari simpanan pokok, simpanan wajib, dana cadangan, dan SHU tahun berjalan. Berdasarkan uraian masalah tersebut, maka penelitian ini bertujuan untuk menganalisis pendapatan rumah tangga, alokasi penggunaan kredit, dan faktor faktor yang mempengaruhi peluang tingkat pengembalian kredit anggota Koperasi Pertanian Seandanan.

\section{METODE PENELITIAN}

Metode penelitian yang digunakan pada penelitian ini adalah studi kasus. Pemilihan lokasi dilakukan secara sengaja (purposive) dengan pertimbangan bahwa Koperasi Pertanian Seandanan cukup menarik, karena walaupun mulai berdiri dengan modal sendiri dan belum mendapatkan bantuan dana sekalipun dari pemerintah, koperasi mampu memberikan akses permodalan kepada petani hingga saat ini dan dapat menghasilkan jumlah SHU yang cukup besar.

Penelitan ini menggunakan 70 orang petani padi anggota Koperasi Pertanian Seandanan sebagai responden. Hal ini karena mayoritas anggota koperasi merupakan petani padi. Data yang digunakan dalam penelitian ini adalah data primer yang diperoleh dari wawancara dengan petani padi anggota koperasi dan data sekunder yang berasal
Dinas Koperasi dan UMKM Kabupaten Pesawaran dan intansi lembaga terkait dengan koperasi.

Metode analisis data untuk menganalisis pendapatan rumah tangga petani padi anggota Koperasi Pertanian Seandanan mengacu pada penelitian Fadillah, Abidin, dan Kalsum (2014), yaitu diperoleh dengan cara menjumlahkan pendapatan keluarga yang berasal dari kegiatan on farm, off farm, dan non farm. Oleh karena itu, pendapatan rumah tangga anggota koperasi dapat diperoleh dengan cara menjumlahkan pendapatan keluarga dari usahatani, pendapatan di luar usahatani, pendapatan non pertanian, dan MEK tunai dengan rumus sebagai berikut:

$\operatorname{Pr}$

$$
\begin{aligned}
= & \mathrm{P} \text { on farm }+\mathrm{P} \text { off farm }+\mathrm{P} \text { non farm } \\
& +\mathrm{P} \text { MEK tunai }
\end{aligned}
$$

Keterangan :

$$
\begin{aligned}
\mathrm{P} \text { rt } & \text { Pendapatan rumah tangga petani } \\
& \text { padi anggota koperasi (Rp/tahun) } \\
\mathrm{P} \text { on farm }= & \text { Pendapatan usahatani pdi (Rp/tahun) } \\
\mathrm{P} \text { off farm = } & \text { Pendapatan usahatani selain dari } \\
& \text { usatani padi (Rp/tahun) } \\
\mathrm{P} \text { non farm }= & \begin{array}{l}
\text { Pendapatan dari luar pertanian } \\
\text { (Rp/tahun) }
\end{array} \\
\text { MEK tunai }= & \text { Pendapatan dari (SHU) }(\mathrm{Rp} / \text { tahun })
\end{aligned}
$$

Metode analisis alokasi pemanfaatan kredit oleh anggota koperasi menggunakan metode analisis deskriptif kuantitatif. Untuk mengetahui pengaruh faktor-faktor kelancaran pengembalian kredit, digunakan analisis binary logit jika petani lancar membayar kredit maka akan diberi skor 1 , dan jika tidak lancar maka diberi 0 .

Menurut Suliyanto (2011), model logit membuat probabilitas dari variabel-variabel yang diobservasi, yaitu $\mathrm{X} 1, \mathrm{X} 2$, dan seterusnya bertujuan untuk menemukan nilai terbaik bagi masing-masing koefisien. Variabel bebas model terdiri dari jumlah peminjaman kredit (Rp/tahun), tingkat pendidikan petani (tahun), pendapatan rumah tangga anggota koperasi (Rp/tahun), dan alokasi penggunaan kredit produktif dengan dummy, yaitu 0 dan 1 , nilai 1 untuk alokasi kredit cenderung lebih banyak kegiatan produktif dan nilai 0 untuk alokasi kredit cenderung lebih banyak kegiatan konsumtif (D).

Model logit dinyatakan sebagai :

$\mathrm{P}_{\mathrm{i}}=\mathrm{F}\left(\mathrm{Z}_{\mathrm{i}}\right)=\mathrm{F}\left(\alpha+\beta \mathrm{X}_{\mathrm{i}}\right)$

$\mathrm{P}_{\mathrm{i}}=1 /\left(1+\mathrm{e}^{-\mathrm{Zi}}\right)$

$\mathrm{P}_{\mathrm{i}}=1 /\left(1+\mathrm{e}^{-\left(\alpha+\beta \mathrm{Xi}_{\mathrm{i}}\right)}\right)$ 
Tabel 1. Rata-rata pendapatan rumah tangga anggota Koperasi Pertanian Seandanan tahun 2018

\begin{tabular}{lrr}
\hline \multicolumn{1}{c}{$\begin{array}{c}\text { Sumber } \\
\text { Pendapatan }\end{array}$} & \multicolumn{1}{c}{$\begin{array}{c}\text { Rata-rata } \\
\text { Pendapatan (Rp) }\end{array}$} & $\begin{array}{r}\text { Persentase } \\
(\%)\end{array}$ \\
\hline On farm & & \\
Usahatani padi & & \\
MT I & $9.692 .789,56$ & 38,53 \\
MT II & $7.966 .991,84$ & 31,67 \\
Budidaya ikan & $235.000,00$ & 0,93 \\
\hline Jumlah & $17.894 .781,40$ & 71,13 \\
\hline Off farm & $942.857,14$ & 5,45 \\
Non farm & $4.537 .714,29$ & 16,68 \\
MEK tunai & $1.711 .312,47$ & 6,74 \\
\hline Jumlah total & $26.947 .110,55$ & 100,00 \\
\hline
\end{tabular}

Untuk mencari Zi menggunakan rumus:

$\mathrm{Zi}=\operatorname{Ln}\left[\frac{P_{\mathrm{i}}}{1-\mathrm{Pi}}\right]=\alpha+\beta_{1} \mathrm{X}_{1}+\beta_{2} \mathrm{X}_{2}+\beta_{3} \mathrm{X}_{3}+\mathrm{dD}+\mathrm{e}$

Keterangan:

$\mathrm{Zi} \quad=$ Tingkat pengembalian kredit $\mathrm{Zi}=1$ : anggota membayar kredit lancar

$=$ Tingkat pengembalian kredit $\mathrm{Zi}=0$ :anggota membayar tidak lancar

$\alpha \quad=$ Intersep

$\mathrm{X} 1=$ Jumlah peminjaman kredit (Rp/tahun)

$\mathrm{X} 2$ = Pendapatan rumah tangga (Rp/tahun)

X3 = Tingkat pendidikan (tahun)

$\mathrm{D}=$ Alokasi penggunaan kredit

D $\quad=1$ :pemanfaatan produktif $>$ pemanfaatan konsumtif

$\mathrm{D} \quad=0$ :pemanfaatan produktif $<$ pemanfaatan konsumtif

$\mathrm{e}=$ Error term

$\mathrm{Pi} \quad=$ Probabilitas

$\beta 1, \beta 2,=$ Koefisien variabel bebas

$\beta 3, \beta 4,=$ Koefisien variabel bebas

\section{HASIL DAN PEMBAHASAN}

\section{Anggota Koperasi Pertanian Seandanan}

Koperasi Pertanian Seandanan dibentuk pada tanggal 1 Januari 2012 dan secara resmi mendapatkan Badan Hukum: 023/BH/X.II/III.8/I/ 2014 pada tanggal 9 Januari 2014. Koperasi Pertanian Seandanan bergerak di bidang pertanian dengan satu unit usaha yaitu simpan pinjam. Responden pada penelitian ini adalah petani padi anggota koperasi, karena sebagian besar anggota koperasi merupakan petani padi. Sebagian besar petani padi memiliki tingkat pendidikan SMA, yaitu sebesar 47,14 persen, lulusan S1 sebesar 1,43 persen, lulusan SMP sebesar 37,14 dan lulusan SD sebesar 14,29 persen.

Responden anggota Koperasi Pertanian Seandanan berjumlah 70 orang dan apabila dilihat dari klasifikasi umur secara ekonomi, rata-rata petani padi anggota Koperasi Pertanian Seandanan masuk ke dalam kelompok umur produktif dengan rentang umur 25-45 tahun yaitu sebanyak 69 petani atau 98 persen. Jumlah petani padi anggota Koperasi Pertanian Seandanan yang termasuk ke dalam kelompok umur tidak produktif hanya sebanyak

1 petani atau 2 persen. Rata-rata pengalaman berusahatani padi responden adalah 18 tahun, terendah adalah 8 tahun dan pengalaman tertinggi adalah 35 tahun. Petani padi memiliki rata-rata luas lahan yaitu sebesar 0,56 ha, luas lahan petani tertinggi adalah $2 \mathrm{Ha}$, dan terendah 0,25 ha.

\section{Pendapatan Rumah Tangga Anggota Koperasi Pertanian Seandanan}

Tabel 1 menunjukkan bahwa pendapatan on farm memiliki kontribusi terbesar untuk pendapatan rumah tangga dengan persentase sebesar 71,13 persen. Kegiatan on farm dibedakan menjadi dua, yaitu kegiatan usahatani padi (on farm utama) dan budidaya ikan(on farm bukan utama), akan tetapi dari kedua kegiatan on farm tersebut yang memiliki kontribusi besar pada pendapatan rumah tangga adalah usahatani padi. Pendapatan usahatani padi mengalami penurunan dari musim tanam I ke musim tanam II, hal ini berbanding terbalik dengan harga hasil produksi di musim tanam II yang lebih tinggi dibandingkan musim tanam I dengan selisih harga sebesar Rp500,00. Penyebab utama dari penurunan produksi padi tersebut adalah serangan hama wereng dan penurunan kualitas benih padi yang digunakan pada musim tanam II oleh petani. Rata-rata pendapatan rumah tangga anggota Koperasi Pertanian Seandanan dapat dilihat pada Tabel 1.

Pendapatan atas biaya tunai pada musim tanam I dan II secara berturut-turut, yaitu sebesar Rp9.692.789,56 dan Rp7.966.991,84. Pendapatan atas biaya tunai dari usahatani padi musim tanam II mengalami penurunan dari musim tanam I, karena produksi yang menurun. Selisih pendapatan atas biaya tunai usahatani padi antara musim tanam I dan II, yaitu sebesar Rp1.725.797,72. Nilai R/C atas biaya tunai dan total usahatani padi pada musim tanam I secara berurut-turut, yaitu 3,46 dan 
Ilmu Ilmu Agribisnis: Journal of Agribusiness Science, 9(3), Agustus 2021

Tabel 2. Pendapatan dan R/C usahatani padi musim tanam I dan II anggota Koperasi Pertanian Seandanan Per 1 Ha tahun 2018.

\begin{tabular}{|c|c|c|c|c|c|c|c|c|}
\hline \multirow[b]{2}{*}{ No } & \multirow[b]{2}{*}{ Uraian } & \multirow[b]{2}{*}{ Sat } & \multicolumn{3}{|c|}{ MT I } & \multicolumn{3}{|c|}{ MT II } \\
\hline & & & Jumlah & $\begin{array}{l}\text { Harga } \\
\text { (Rp/sat) }\end{array}$ & $\begin{array}{l}\text { Nilai } \\
\text { (Rp) }\end{array}$ & Jumlah & $\begin{array}{l}\text { Harga } \\
\text { (Rp/sat) }\end{array}$ & $\begin{array}{l}\text { Nilai } \\
\text { (Rp) }\end{array}$ \\
\hline \multirow[t]{2}{*}{1} & Penerimaan & & & & & & & \\
\hline & $\begin{array}{l}\text { Produksi Padi } \\
\text { Biaya }\end{array}$ & $\mathrm{Kg}$ & $5.409,85$ & $4.500,00$ & $24.344 .311,22$ & $4.590,56$ & $4.500,00$ & $20.657 .525,51$ \\
\hline \multirow[t]{23}{*}{2} & Produksi & & & & & & & \\
\hline & $\begin{array}{l}\text { I. Biaya Tunai } \\
\text { Biaya Variabel }\end{array}$ & & & & & & & \\
\hline & Benih & $\mathrm{Kg}$ & 27,91 & $7.000,00$ & $195.357,14$ & 30,51 & $7.000,00$ & $213.571,43$ \\
\hline & Pupuk NPK & $\mathrm{Kg}$ & 127,55 & $2.400,00$ & $306.122,45$ & 107,14 & $2.400,00$ & $257.142,86$ \\
\hline & Pupuk TSP & $\mathrm{Kg}$ & 129,40 & $2.500,00$ & $323.498,96$ & 121,17 & $2.500,00$ & $302.933,67$ \\
\hline & Pupuk KCL & $\mathrm{Kg}$ & 70,15 & $3.000,00$ & $210.459,18$ & 72,70 & $3.000,00$ & $218.112,24$ \\
\hline & Pupuk Urea & $\mathrm{Kg}$ & 234,69 & $2.000,00$ & $469.387,76$ & 216,84 & $2.000,00$ & $433.673,47$ \\
\hline & Gramoxone & liter & 1,81 & $60.000,00$ & $108.673,47$ & 1,59 & $60.000,00$ & $95.663,27$ \\
\hline & Fastac & $\mathrm{ml}$ & 905,61 & 150,00 & $135.841,84$ & 910,71 & 150,00 & $136.607,14$ \\
\hline & Metindo & $\mathrm{Kg}$ & 0,30 & $200.000,00$ & $59.642,86$ & 0,27 & $200.000,00$ & $53.673,47$ \\
\hline & Regent & $\mathrm{ml}$ & 116,07 & 500,00 & $58.035,71$ & 109,69 & 500,00 & $54.846,94$ \\
\hline & TKLK & $\mathrm{HOK}$ & 83,44 & $60.000,00$ & $5.006 .264,58$ & 75,45 & $60.000,00$ & $4.526,813,05$ \\
\hline & Biaya Karung & $\mathrm{Rp}$ & & & $162.474,49$ & & & $137.716,84$ \\
\hline & Total Biaya Tun & & & & $7.035 .758,44$ & & & $6.430,754,37$ \\
\hline & $\begin{array}{l}\text { II. Biaya } \\
\text { diperhitungkan }\end{array}$ & & & & & & & \\
\hline & Biaya Pajak & $\mathrm{Rp}$ & & & $17.633,93$ & & & $17,633,93$ \\
\hline & TKDK & НоК & 11,83 & $60.000,00$ & $709.821,43$ & 10,78 & $60.000,00$ & $646,683,67$ \\
\hline & Penyusutan & & & & & & & \\
\hline & Biaya Tetap & & & & & & & \\
\hline & Alat & $\mathrm{Rp}$ & & & $164.828,87$ & & & $164,828,87$ \\
\hline & Total Biaya & & & & & & & \\
\hline & Diperhitungkan & & & & $892.284,23$ & & & $811,512,54$ \\
\hline & III. Total Biaya & & & & $7.928 .042,67$ & & & $7.242 .266,92$ \\
\hline \multirow[t]{5}{*}{3} & Pendapatan & & & & & & & \\
\hline & I. Pendapatan & & & & & & & \\
\hline & atas Biaya & & & & & & & \\
\hline & Tunai & $\mathrm{Rp}$ & & & $17.308 .552,78$ & & & $14.226 .771,14$ \\
\hline & $\begin{array}{l}\text { II. Pendapatan } \\
\text { atas Biava Tota }\end{array}$ & & & & 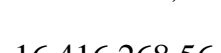 & & & 13.415 .258 .59 \\
\hline \multirow[t]{5}{*}{4} & $\begin{array}{l}\text { atas Braya lotal } \\
\text { R/C Ratio }\end{array}$ & К中 & & & $16.416 .268,56$ & & & $15.41 J .250,53$ \\
\hline & I. $\mathrm{R} / \mathrm{C}$ atas & & & & & & & \\
\hline & Biaya Tunai & & & & 3,46 & & & 3,21 \\
\hline & II. $\mathrm{R} / \mathrm{C}$ atas & & & & & & & \\
\hline & Biaya Total & & & & 3,07 & & & 2,85 \\
\hline
\end{tabular}

Hal itu menunjukkan bahwa setiap Rp1,00 biaya tunai/total yang dikeluarkan untuk usahatani padi, maka akan memberikan penerimaan sebesar Rp3,46 dan Rp3,07. Nilai R/C atas biaya tunai dan total usahatani padi pada musim tanam II secara berurut, yaitu 3,21 dan 2,85, maka dapat disimpulkan bahwa semua usahatani, baik pada musim tanam I dan II, layak dijalankan karena menguntungkan.

Penelitian ini sejalan dengan penelitian Mita, Haryono, dan Marlina (2018), yang menyebutkan bahwa usahatani padi layak dan menguntungkan, karena $\mathrm{R} / \mathrm{C}>1$. Rata-rata pendapatan usahatani padi per hektar atas biaya tunai pada penelitian ini tergolong tinggi dibandingkan penelitian Mita Haryono, dan Marlina (2018) yaitu, sebesar Rp20.042.755,83, perbedaan tersebut dikarenakan oleh lokasi dan kondisi penelitian yang berbeda. Selanjutnya pendapatan off farm merupakan pendapatan yang memiliki kontribusi terkecil dalam pendapatan rumah tangga petani padi anggota koperasi yaitu sebesar 5,45 persen. Hal ini dikarenakan jumlah petani yang memiliki kegiatan off farm hanya sedikit dan kegiatan tersebut dilakukan petani hanya sebagai kegiatan sampingan. 
Tabel 3. Rata-rata manfaat ekonomi Koperasi Pertanian Seandanan tahun 2017

\begin{tabular}{lrr}
\hline $\begin{array}{c}\text { Manfaat Ekonomi } \\
\text { Koperasi }\end{array}$ & \multicolumn{1}{c}{$\sum$} & \multicolumn{1}{c}{$\%$} \\
\hline MEK Tunai & $1.711 .312,47$ & 4,89 \\
MEK Diperhitungkan & $88.014,84$ & 95,11 \\
\hline Jumlah & $1.799 .327,31$ & 100,00 \\
\hline
\end{tabular}

Pendapatan rumah tangga petani padi anggota koperasi diperoleh juga dari manfaat ekonomi koperasi tunai yang berasal dari perolehan SHU koperasi. Rata-rata penerimaan SHU anggota koperasi berdasarkan RAT tahun 2017 yaitu, sebesar Rp1.711.312,47. Penerimaan SHU tertinggi sebesar Rp3.811.500,00 sedangkan penerimaan SHU terendah sebesar Rp280.000,00.

Besaran SHU yang diperoleh anggota koperasi disesuaikan dengan partisipasi anggota terhadap koperasi, kehadiran setiap kegiatan koperasi, dan ketepatan waktu pembayaran simpanan wajib. Selain itu, acuan dalam pembagian SHU untuk anggota Koperasi Pertanian Seandanan berdasarkan perbandingan simpanan anggota, dan transaksi pinjaman anggota. Rata-rata manfaat ekonomi tunai yang diterima oleh anggota koperasi lebih besar dibandingkan dengan manfaat ekonomi yang diperhitungkan. Rata-rata manfaat ekonomi tunai yang diterima anggota koperasi pada tahun 2017, yaitu sebesar Rp1.711.312,47, sedangkan rata-rata manfaat ekonomi diperhitungkan sebesar Rp88.014,84. Penelitian ini sejalan dengan penelitian Putri, Lestari, dan Kasymir (2018), yang menyebutkan bahwa anggota koperasi memperoleh manfaat ekonomi tunai lebih besar dibandingkan manfaat ekonomi diperhitungkan.

Perbedaan pada penelitian ini, yaitu manfaat ekonomi yang diterima anggota koperasi lebih besar dibandingkan pada penelitian tersebut. Hal ini terjadi karena perbedaan pada acuan sistem pembagian SHU yang ditentukan oleh Koperasi Pertanian Seandanan. Rata-rata manfaat ekonomi Koperasi Pertanian Seandanan dapat disajikan pada Tabel 3.

Perolehan SHU anggota koperasi berdasarkan perbandingan simpanan, yaitu jumlah simpanan anggota dikalikan 20 persen, sehingga diperoleh SHU anggota koperasi, sedangkan perolehan SHU berdasarkan perbandingan transaksi pinjaman, yaitu jumlah pinjaman anggota dikalikan 15 persen, sehingga diperoleh SHU anggota koperasi. Berdasarkan perbandingan simpanan, SHU anggota koperasi pada tahun 2017 diperoleh ratarata sebesar Rp853.407,75 dan berdasarkan pinjaman rata-rata sebesar Rp639.962,40.

Berdasarkan Tabel 3, rata-rata MEK tunai yang diterima oleh anggota koperasi tahun 2017, yaitu sebesar Rp1.711.312,47, mampu berkontribusi terhadap pendapatan rumah tangga sebesar 6,02 persen. Kontribusi ini lebih kecil jika dibandingkan dengan penelitian Seta, Lestari dan Situmorang (2016) yang menyebutkan kontribusi MEK tunai terhadap pendapatan rumah tangga anggota Koperasi Gunung Madu yaitu sebesar 14,28 persen. Hal ini terjadi karena terdapat perbedaan pekerjaan responden, yaitu pada anggota Koperasi Gunung Madu merupakan karyawan, bukan petani sehingga berdampak pada pendapatan rumah tangga.

Selain itu pendapatan non farm memiliki kontribusi besar terhadap pendapatan rumah tangga yaitu, sebesar 16,68 persen yang bersumber dari berbagai kegiatan petani padi anggota Koperasi Pertanian Seandanan diantaranya aparatur sipil negara, penjahit, reparasi kendaraan, pedagang, buruh non pertanian, dan aparatur desa. Rata-rata pendapatan rumah tangga anggota Koperasi Pertanian Seandanan, yaitu sebesar 25.155.543,87 per tahun, yang bersumber dari pendapatan On farm, Off farm, Non farm, dan manfaat ekonomi koperasi tunai. Pendapatan ini tergolong tinggi jika dibandingkan dengan penelitian Syahputra, Lestari dan Prasmatiwi (2018), yang menyebutkan bahwa pendapatan rumah tangga anggota Koperasi Sumber Peternakan, yaitu Rp20.431.769,00 per tahun. Hal ini dikarenakan adanya perbedaan waktu dan tempat penelitian.

\section{Analisis Alokasi Penggunaan Kredit Anggota Koperasi Pertanian Seandanan}

Analisis alokasi penggunaan kredit adalah suatu pemanfaatan dana kredit oleh anggota koperasi dalam memenuhi kebutuhan primer maupun kebutuhan sekunder. Petani padi anggota Koperasi Pertanian Seandanan dalam meminjam kredit pada koperasi berdasarkan kebutuhannya, sehingga masing-masing anggota memiliki jumlah peminjaman dan waktu peminjaman yang berbeda. Berdasarkan buku RAT tahun 2017 jumlah pinjaman kredit tertinggi yaitu sebesar Rp12.840.000, dan terendah sebesar Rp850.000 dengan rata-rata per tahun pinjaman kredit yaitu, sebesar Rp5.070.423,46. 
Tabel 4. Alokasi penggunaan kredit anggota Koperasi Pertanian Seadanan tahun 2018

\begin{tabular}{lrr}
\hline \multicolumn{1}{c}{$\begin{array}{c}\text { Alokasi } \\
\text { Kredit }\end{array}$} & $\begin{array}{c}\text { Jumlah } \\
\text { Kredit (Rp) }\end{array}$ & $\begin{array}{c}\text { Persentase } \\
(\%)\end{array}$ \\
\hline Konsumtif & & \\
\hline Pangan & $812.949,86$ & 16,03 \\
Non pangan & $1.273 .902,17$ & 25,12 \\
\hline Jumlah & $2.086 .853,03$ & 41,15 \\
\hline Produktif & & \\
\hline On farm & $2.649 .714,46$ & 52,25 \\
Off farm & $176.571,43$ & 3,48 \\
Non farm & $143.000,00$ & 2,82 \\
\hline Jumlah & $2.969 .285,89$ & 58,85 \\
\hline Jumlah Total & $5.070 .423,46$ & 100,00 \\
\hline
\end{tabular}

Pemanfaatan dana kredit oleh anggota Koperasi Pertanian Seandanan dibedakan menjadi dua jenis, yaitu pemanfaatan kegiatan produktif dan konsumtif. Tabel 4 menunjukkan sebesar 58,55 persen alokasi kredit anggota koperasi digunakan untuk kegiatan produktif, yang terdiri dari kegiatan on farm, off farm, dan non farm. Pada penggunaan kredit konsumtif untuk kebutuhan non pangan lebih tinggi dibandingkan dengan kebutuhan pangan yang memiliki selisih sebesar 14,24 persen. Hal ini karena petani anggota koperasi memiliki kebutuhan yang besar diluar kebutuhan pangan seperti keperluan membayar sekolah anak, membayar listrik, keperluan acara pernikahan, dan lain-lain.

\section{Analisis Faktor-faktor yang Mempengaruhi Peluang Tingkat Pengembalian Kredit Anggota Koperasi Pertanian Seandanan}

Analisis binary logit digunakan karena variabel dependen terdiri dari dua kategori, yaitu peluang tingkat pengembalian kredit lancar dan tidak lancar. Jadi variabel terikat (Y) nilai (1) bila lancar dalam membayar kredit, dan sebaliknya nilai (0) bila tidak lancar. Variabel bebas (X) pada penelitian ini adalah jumlah peminjaman kredit dengan satuan Rp/tahun (X1), tingkat pendidikan dengan satuan tahun (X2), pendapatan rumah tangga petani padi anggota koperasi dengan satuan rupiah per tahun (X3), dan alokasi penggunaan kredit (D) dimana nilai (1) bila alokasi penggunaan kredit produktif $>$ dari penggunaan konsumtif, dan sebaliknya bila alokasi penggunaan kredit produktif < penggunaan konsumtif bernilai $(0)$.

Berdasarkan Tabel 5, diperoleh nilai McFadden Rsquared sebesar 0,6618 artinya bahwa 66,18 persen variasi peluang tingkat pengembalian kredit petani padi anggota koperasi dapat dijelaskan oleh variabel yang terdapat di dalam model, yaitu jumlah peminjaman kredit, tingkat pendidikan, pendapatan rumah tangga, dan alokasi penggunaan kredit produktif. Sisanya, sebesar 33,82 persen dijelaskan oleh variabel-variabel lain yang tidak dimasukkan ke dalam model.

Pengaruh variabel independen terhadap variabel dependen secara bersama-sama diketahui dengan menggunakan uji LR statistik. Nilai LR statistik pada penelitian ini sebesar 32,9256 dan nilai probability LR statistik adalah sebesar 0,0000001< 0,01 artinya variabel peminjaman kredit, tingkat pendidikan, pendapatan rumah tangga, dan alokasi penggunaan kredit petani padi anggota koperasi secara bersama-sama berpengaruh nyata terhadap tingkat kelancaran pengembalian kredit petani padi anggota koperasi dengan tingkat kepercayaan sebesar 99 persen. Hal ini karena ada beberapa faktor diantaranya pada tingkat pendidikan petani padi anggota Koperasi Pertanian Seandanan merupakan lulusan SMA, dan sebagian penggunaan kredit digunakan untuk kegiatan yang bersifat produtif. Variabel independen yang berpengaruh nyata terhadap peluang kelancaran pengembalian kredit adalah tingkat pendidikan dan alokasi penggunaan kredit. Hasil pengujian menunjukkan bahwa variabel tingkat pendidikan memiliki nilai z-statistik sebesar 2,465434 dengan probabilitas 0,0137. Artinya, tingkat pendidikan memiliki pengaruh yang signifikan terhadap peluang kelancaran pengembalian kredit petani padi anggota Koperasi Pertanian Seandanan dengan tingkat kepercayaan 95 persen. Hal ini disebabkan, mayoritas tingkat pendidikan petani padi anggota Koperasi Pertanian Seandanan adalah sekolah SMA sehingga hal ini mempengaruhi keberhasilan petani dalam mengelola usahatani padi yang berujung pada kelancaran pengembalian kredit. Nilai odds rasio variabel tingkat pendidikan adalah sebesar 1,0138 artinya setiap kenaikan variabel tingkat pendidikan sebesar satu tahun, maka akan memunculkan odds ratio sebesar 1,0138 atau terjadi peluang peningkatan kelancaran pengembalian kredit sebesar 1,0138 kali. Hasil penelitian ini sejalan dengan penelitian Utami (2014), yang menyatakan bahwa tingkat pendidikan berpengaruh nyata terhadap kelancaran kredit anggota Koperasi Kredit Swastiastu Singaraja di Provinsi Bali.

Selanjutnya, variabel alokasi penggunaan kredit memiliki nilai z-statistik sebesar 2,561697 dengan probabilitas 0,0104 . 
Tabel 5. Hasil regresi binary logit faktor-faktor yang mempengaruhi tingkat pengembalian kredit anggota Koperasi Pertanian Seandanan

\begin{tabular}{lrrrrr}
\hline \multicolumn{1}{c}{ Variable } & Coefficient & \multicolumn{1}{c}{ Std. Error } & \multicolumn{1}{c}{ z-Statistic } & \multicolumn{1}{c}{ Prob. } & \multicolumn{1}{c}{ Odd- Ratio } \\
\hline \hline 'constant & $-5,299999$ & 2,693413 & $-1,967763$ & 0,0491 & 1,0503 \\
Jumlah peminjaman kredit (X1) & $-1,83 \mathrm{E}-07$ & $1,64 \mathrm{E}-07$ & $-1,118826$ & 0,2632 & 1,3011 \\
Tingkat pendidikan (X2) & $0,625524^{*}$ & 0,253718 & 2,465434 & 0,0137 & 1,0138 \\
Pendapatan rumah tangga(X3) & $4,50 \mathrm{E}-08$ & $4,25 \mathrm{E}-08$ & 1,058821 & 0,2897 & 1,3360 \\
Alokasi penggunaan kredit(D) & $2,165928^{*}$ & 0,845505 & 2,561697 & 0,0104 & 1,0104 \\
\hline \hline Log likelihood & $-8,413996$ & & \\
Restr. log likelihood & $-24,87680$ McFadden R-squared & & 0,661773 \\
LR statistic & 32,92561Prob(LR statistic) & & & & \\
\end{tabular}

Artinya, alokasi penggunaan kredit memiliki pengaruh yang signifikan terhadap kelancaran pengembalian kredit dikarenakan probabilitas kurang dari 0,05 dengan tingkat kepercayaan sebesar 95 persen. Nilai koefisien bernilai positif, artinya apabila alokasi penggunaan kredit lebih banyak digunakan untuk kegiatan produktif, maka peluang kelancaran pengembalian kredit akan meningkat sebesar 2,1659 satuan. Hal ini disebabkan, semakin besar alokasi penggunaan kredit produktif yang dilakukan petani padi anggota Koperasi Pertanian Seandanan, maka akan

meningkatkan kelancaran pengembalian kredit, dan begitupun sebaliknya. Nilai odds rasio adalah sebesar 1,0104 , artinya setiap alokasi penggunaan kredit lebih banyak digunakan untuk kegiatan produktif, maka akan terjadi peningkatan peluang kelancaran pengembalian kredit petani padi anggota Koperasi Pertanian Seandanan sebesar 1,0104 kali.

Variabel independen yang tidak berpengaruh nyata terhadap tingkat kelancaran pengembalian kredit adalah jumlah pinjaman kredit dan pendapatan rumah tangga. Hal ini sejalan dengan penelitian Meizari, Ismono, dan Soelaiman (2015), menyatakan bahwa jumlah pengambilan kredit tidak berpengaruh pada tingkat pengembailan kredit usaha kelompok dalam pengembangan usaha agribisnis pedesaan (PUAP) di Kecamatan Gading Rejo Kabupaten Lampung Tengah.

\section{KESIMPULAN}

Rata-rata pendapatan rumah tangga yang diterima anggota koperasi sebesar Rp26.947.110,55per tahun yang bersumber dari pendapatan on farm atas biaya tunai MT I dan MT II yaitu sebesar Rp9.692.789,56 dan Rp7.966.991,84, pendapatan off farm sebesar Rp1370.714,29, pendapatan non farm sebesar Rp4.194.857,14 dan manfaat ekonomi koperasi tunai yaitu sebesar
Rp1.711.312,47 yang diperoleh dari pembagian SHU berdasarkan perbandingan simpanan dan transaksi pinjaman. Alokasi penggunaan kredit sebesar 58,55 persen digunakan untuk kegiatan produktif dan sisanya, yaitu sebesar 41,16 persen digunakan untuk kegiatan yang bersifat konsumtif. Faktor-faktor yang berpengaruh terhadap kelancaran pengembalian kredit anggota koperasi adalah tingkat pendidikan dan alokasi penggunaan kredit produktif.

\section{DAFTAR PUSTAKA}

Batubara MM. 2012. Koperasi Pertanian. Faperta Universitas Muhammadiyah Palembang. Palembang.

Febrianka VW. 2016. Kinerja koperasi studi tentang faktor-faktor penyebab tidak aktifnya koperasi gotong royong Kota Blitar. JKMP, 4(3): 7-8. http://jurnal. fp.unair. ac.id/ 441/240 kmp5d2543e464. [27 Desember 2018].

Fadillah, Abidin Z, dan Kalsum U. 2014. Pendapatan dan kesejahteraan rumah tangga nelayan anggota Koperasi Obor di Kota Bandar Lampung. Jurnal Ilmu Ilmu Agribisnis, $\quad 2(3): \quad 6-9$ http://jurnal.fp.unila.ac.id /index. php/ JIA/article/view/563. [2 Juli 2019].

Meizari K, Ismono RH, dan Soelaiman A. 2015. Faktor-faktor yang mempengaruhi kredit usaha kelompok dalam program PUAP di Kecamatan Bangun Rejo. Jurnal Ilmu Ilmu Agribisnis, $\quad 3(4): \quad 35-43$ htp:/jurnal.fp.unila.ac.id /index.php /JIA/ article/view/1084/989. [8 Juli 2019].

Mita YT, Haryono D, dan Marlina L. 2018. Analisis pendapatan dan faktor-faktor yang mempengaruhi pengambilan keputusan usahatani penangkaran benih padi di Kabupaten Pesawaran. Jurnal Ilmu Ilmu Agribisnis, 7(2): 159-162. http://jurnal. fp.unila. ac.id/index.php/JIA/ article/view/241/240. [8 Desember 2019]. 
Putri DL, Lestari DAH dan Kasymir E. 2018. Analisis manfaat koperasi, pendapatan, dan tingkat kesejahteraan anggota koperasi LKMA gapoktan sari makmur di Kecamatan Metro Timur Kota Metro. Jurnal Ilmu Ilmu Agribisnis, 7(2): 159-162. http://jurnal. fp.unila. ac.id/ index. php/JIA/article/view/231/230. [8 Juli 2019].

Roepke J. 2003. Ekonomi Koperasi Teori dan Manajemen. Salemba Empat. Jakarta.

Suliyanto. 2011. Ekonometrika Terapan : Teori dan Aplikasi dengan SPSS. Penerbit CV Andi Offset. Yogyakarta.

Syahputra F, Lestari DAH, dan Prasmatiwi FE. 2018. Analisis struktur dan distribusi pendapatanrumah tangga serta tingkat kesejahteraan anggota KSUP MDIT di Kecamatan Gisting Kabupaten Tanggamus. Jurnal Ilmu Ilmu Agribisnis, 5(1): 67-75. http://jurnal. fp.unila. ac.id/index.php/JIA/article/view/241/240. [9 Desember 2019].

Seta AP, Lestari DAH, Situmorang S, 2016. Manfaat ekonomi dan non ekonomi koperasi gunung madu (kgm) di PT Gunung Madu Plantations (PT GMP) Kabupaten Lampung Tengah. Jurnal Ilmu Ilmu Agribisnis, 3(1): 711. http://jurnal. fp.unila.ac.id/index.php/JIA/article/view/241 1240. [9 Desember 2019].

Utami, PS 2014. Analisis sistem pengendalian intern dan penanganan kredit macet pada Koperasi Swastiastu Singaraja tahun 2012. Jurnal jurnal ilmu pertanian, 4(1)2123.https://ejournal.undiksha.ac.id index.php/JJPE/article/view/1905 